\title{
The Diabetes Epidemic in the Elderly Population in Western Europe: Data from Population-Based Studies
}
W. Rathmann ${ }^{1}$
B. Haastert ${ }^{1}$
A. Icks ${ }^{1}$
C. Herder ${ }^{2}$
H. Kolb ${ }^{2}$
R. Holle ${ }^{3}$
A. Mielck ${ }^{3}$
C. Meisinger ${ }^{4}$
H. E. Wichmann ${ }^{4}$
G. Giani ${ }^{1}$

\author{
Die Diabetes-Epidemie in der älteren Bevölkerung in Westeuropa: Daten aus \\ bevölkerungsbasierten Studien
}

\section{Zusammenfassung}

Valide epidemiologische Daten zum Typ-2-Diabetes-mellitus in der älteren Population sind trotz der mit dieser Erkrankung verbundenen erheblichen individuellen und ökonomischen Belastungen rar in der europäischen Region. Zielsetzung waren eine Erfassung populationsbasierter Daten zum Typ-2-Diabetes sowie der gestörten Glukosetoleranz (Impaired Glucose Regulation, IGR) aus den seit 1990 in Westeuropa mit oralen Glukosetoleranztests durchgeführten Surveys sowie eine Evaluation möglicher Zusammenhänge von Risikofaktoren wie Übergewicht und körperlicher Inaktivität mit der geografischen Variation der Diabetesprävalenz. In der Altersdekade bis 60 Jahre hatten etwa $10 \%$ der Bevölkerung in europäischen Surveys einen bekannten oder neu entdeckten Diabetes. In der Altersgruppe 70 bis 79 Jahre lag die durchschnittliche Diabetesprävalenz bei etwa $25 \%$. Die IGR-Prävalenz stieg ebenfalls mit höherem Alter an und erreichte ein Maximum von 25\% (Männer) bis 30\% (Frauen) bei den über 70-Jährigen. Es fand sich eine große Variation der Diabetesprävalenz in der älteren Bevölkerung in westeuropäischen Ländern, allerdings war ein eindeutiges geografisches Muster nicht erkennbar. Während die alters- und geschlechtsspezifischen Diabetesprävalenzen im deutschen KORA-Survey S4 (1999/2001) (Augsburg) vergleichbar waren mit europäischen Durchschnittszahlen, lagen die IGR-Prävalenzen in Augsburg höher (60-69 Jahre; KORA: Männer: 30,2\%, Frauen: 22,4\% Europa: Männer:

\section{Abstract}

Valid epidemiologic data on type 2 diabetes in the elderly population are scarce in the European Region despite its enormous human and economic burden. The aim was to assess population-based data on type 2 diabetes and impaired glucose regulation (IGR) from surveys carried out in Western Europe since 1990 using oral glucose tolerance tests, and to discuss the possible impact of risk factors on geographic variation, in particular, obesity and physical activity. In the decade below 60 years of age, about $10 \%$ of the population had known or newly diagnosed diabetes in European surveys. In the age group 70 to 79 years, average total diabetes prevalence was about one quarter. IGR prevalences also increased with age, reaching a maximum of $25 \%$ (men) to $30 \%$ (women) above 70 years of age. There was a wide variation of total diabetes prevalence in the elderly population in Western European countries, however, without clear geographical pattern. Whereas age- and sex-specific prevalences for total diabetes in the German KORA Survey S4 (1999/2001) (Augsburg) were comparable to the European average, IGR prevalences were higher in Augsburg (60-69 years: KORA: men: 30.2\%, women: $22.4 \%$ Europe: men: $21.2 \%$, women: $19.0 \%$ ). Thus, there is a huge reservoir for future diabetes cases in the elderly population in Germany. Differences at the population level were found for obesity, nutrition, and sedentary lifestyle in Western Europe. Comparative studies on the predictive values of obesity, physical activity, and

affiliation

${ }^{1}$ Leibniz Institute at the Heinrich Heine University, Institute of Biometrics and Epidemiology, German Diabetes Center, Düsseldorf, Germany

${ }^{2}$ Leibniz Institute at the Heinrich Heine University, German Diabetes Clinic, German Diabetes Center, Düsseldorf, Germany

${ }^{3}$ GSF National Research Center for Environment and Health, Institute of Health Economics and Health Care Management, Neuherberg, Germany

${ }^{4}$ GSF National Research Center for Environment and Health, Institute of Epidemiology, Neuherberg, Germany

correspondence

Dr. Wolfgang Rathmann MSPH (USA) - German Diabetes Center, Leibniz Institute at the Heinrich Heine University·Auf'm Hennekamp 65 · 40225 Düsseldorf·E-mail: rathmann@ddz.uni-duesseldorf.de

bibliography

Gesundheitswesen 2005; 67 Sonderheft 1: S110-S114 @ Georg Thieme Verlag KG Stuttgart • New York DOI $10.1055 / \mathrm{s}-2005-858227$

ISSN 0949-7013 
21,2\%, Frauen: $19,0 \%)$. Daraus ergibt sich ein großes Reservoir für zukünftige Diabetesfälle in der älteren Bevölkerung in Deutschland. In westeuropäischen Ländern bestehen Unterschiede hinsichtlich Übergewicht, Ernährung und körperlicher Aktivität. Zukünftige Studien sollten die prädiktiven Werte von Übergewicht, körperlicher Inaktivität und Ernährungsfaktoren, einschließlich möglicher Interaktionen mit genetischen Markern, in den verschiedenen europäischen Populationen evaluieren.

\section{Schlüisselwörter}

Typ-2-Diabetes · gestörte Glukosetoleranz · Epidemiologie trition and possible interactions with genetic markers in European populations are of interest in the future.

\section{Key words}

Type 2 diabetes · impaired glucose regulation · epidemiology

\section{Introduction}

Type 2 diabetes is one of the most challenging health problems in the 21 st century both in developed and developing countries. It is among the leading causes of death and diabetic macro- and microvascular complications are resulting in increased disability and enormous health care costs [1]. The number of people with diabetes is increasing due to aging of the population and increased prevalence of obesity and physical inactivity [2]. In the European Region, an average total diabetes prevalence of $7.8 \%$ in the adult population (20-79 years) or 48.4 million persons has been estimated in 2003 [1]. This high prevalence is partly a consequence of the relatively old population compared to other regions worldwide. Currently, about one third of the European population is over 50 years of age, which is expected to increase to over $40 \%$ by 2025 [1]. Therefore, without effective prevention programs, diabetes prevalence in Europe is expected to increase to $9.1 \%$ or 58.6 millions in 2025 as estimated by the International Diabetes Federation [1]. This increase will place an enormous financial burden on a declining working age population in Europe.

Despite the increasing prevalence and the human and economic burden, valid epidemiological data on type 2 diabetes in the elderly population is scarce in the European Region [3]. While infectious diseases are carefully monitored, this non-communicable disease is not continuously assessed [3]. A mapping and comparative analysis of type 2 diabetes and its precursor, impaired glucose regulation (IGR), using standardized methods is lacking in Europe. The aim of this review is to evaluate population-based data on type 2 diabetes and IGR prevalence from surveys carried out since 1990 in Western Europe, and to discuss the possible impact of risk factors on geographic variation, in particular, obesity and physical activity.

\section{Methods}

The gold standard to evaluate type 2 diabetes and IGR prevalence in the elderly population is the OGTT (oral glucose tolerance test)-based investigation of a representative sample. Inclusion criteria for the current review were (1) population-based surveys for diabetes using both fasting and $2 \mathrm{~h}$ glucose values after a standard $75 \mathrm{~g}$ OGTT on all participants without known diabetes, (2) surveys from Western European countries, (3) age group above 50 years both including men and women, and (4) surveys which have been carried out after 1990 to control for possible se- cular trends of prevalence. In case that several comparable surveys have been carried out in the same country the most recent was chosen. Due to a large variation of age-strata and laboratory methods in the original publications, data were largely obtained from a recent meta-analysis of European studies (DECODE Study; Diabetes epidemiology: collaborative analysis of diagnostic criteria in Europe) [4]. Glucose concentrations were all transformed to plasma glucose concentrations [4]. In Germany, only one study fulfilled the inclusion criteria. In the KORA Survey S4 (1999/2001), OGTT were carried out in a random sample of 1353 subjects aged 55 to 74 years in the Augsburg region [5]. Age- and sex-specific prevalences of diabetes and IGR were given according to the 1999 WHO criteria [6]. Thus, classification of diabetes was based on both fasting and $2 \mathrm{~h}$ plasma glucose. According to the WHO recommendations IGR is either impaired glucose tolerance (IGT) or impaired fasting glucose (IFG). IGT was defined as $2 \mathrm{~h}$ plasma glucose between 140 to $199 \mathrm{mg} / \mathrm{dl}$ and fasting glucose below $126 \mathrm{mg} / \mathrm{dl}$. Fasting plasma glucose concentrations between 110 and $125 \mathrm{mg} / \mathrm{dl}$ and $2 \mathrm{~h}$ glucose $<140 \mathrm{mg} / \mathrm{dl}$ were classified as IFG. In the KORA Survey, prevalences were calculated accounting for sample design to provide representative population estimates [5].

\section{Results}

The age- and sex-specific prevalences of total diabetes (known and newly diagnosed) and IGR from the KORA Survey S4 (1999/ 2001), Germany, and 13 other European population-based studies (DECODE meta-analysis) combined are given in Table $\mathbf{1}$ In the KORA Survey, the age range was limited to 55 to 74 years (DECODE: 50 to 79 years).

In the Augsburg survey and most of the other European studies, half of total diabetes cases were previously undiagnosed. Total diabetes prevalence (known and undiagnosed) increased with age in both sexes, comprising about one quarter of the population in the age group 70 to 79 years in the DECODE meta-analysis (Table 1). In the decade below 60 years of age, about $10 \%$ of the population had known or newly diagnosed diabetes. IGR prevalences also increased with age, reaching a maximum of $25 \%$ (men) to $30 \%$ (women) in the age-group 70 to 79 years. Significant sex differences were found for diabetes prevalence in the DECODE data. Whereas the prevalence was significantly higher in men than in women aged 50 to 59 years, a larger proportion of women suffered from diabetes in the age group above 70 
years. Up to 70 years, also IGR was more frequent in elderly men than in women in the DECODE analysis.

The age- and sex-specific prevalences for total diabetes observed in the Augsburg region were largely comparable to the DECODE European average estimates, taking into account the different age ranges (Table $\mathbf{1}$ ). Similar to the DECODE data, diabetes preva-

Table 1 Prevalence of total diabetes and impaired glucose regulation (IGR) in the elderly population: KORA Survey S4 (1999/2001) (Augsburg), Germany, and DECODE meta-analysis of 13 European studies

\begin{tabular}{|c|c|c|c|c|c|c|}
\hline & \multirow[b]{2}{*}{$\begin{array}{l}55-59 \\
\text { years }\end{array}$} & \multicolumn{3}{|c|}{ KORA survey } & \multicolumn{2}{|c|}{ DECODE study ${ }^{3}$} \\
\hline & & $\begin{array}{l}60-69 \\
\text { years }\end{array}$ & $\begin{array}{l}70-74 \\
\text { years }\end{array}$ & $\begin{array}{l}50-59 \\
\text { years }\end{array}$ & $\begin{array}{l}60-69 \\
\text { years }\end{array}$ & $\begin{array}{l}70-79 \\
\text { years }\end{array}$ \\
\hline \multicolumn{7}{|c|}{ Total diabetes ${ }^{1}(\%)$} \\
\hline men & $16.6^{*}$ & 18.1 & 23.1 & $10.1^{*}$ & 15.5 & $23.4^{*}$ \\
\hline women & $8.6^{*}$ & 16.7 & 17.0 & $7.8^{*}$ & 16.1 & $27.3^{*}$ \\
\hline \multicolumn{7}{|l|}{$I_{G R}^{2}(\%)$} \\
\hline men & 18.1 & $30.2^{*}$ & 29.2 & $19.2^{*}$ & $21.2^{*}$ & 24.8 \\
\hline women & 12.6 & $22.4^{*}$ & 25.5 & $14.3^{*}$ & $19.0^{*}$ & 29.6 \\
\hline
\end{tabular}

${ }^{1}$ known and newly diagnosed diabetes (OGTT) ${ }^{2}$ impaired glucose tolerance or impaired fasting glucose (1999 WHO $)^{3}$ The DECODE Study Group. Diabetes Care 2003; 26: 61-69

${ }^{*} \mathrm{p}<0.05$ for sex differences

Table 2 Description of population-based studies on diabetes in the elderly population in Western Europe from 1990: DECODE Study and KORA Survey S4 (1999/2001)

\begin{tabular}{lllllll}
\hline study & $\begin{array}{l}\text { mean age } \\
\text { (range) }\end{array}$ & $\begin{array}{l}\text { participants, } \\
\text { n (\%) }\end{array}$ & $\begin{array}{l}\text { men } \\
\text { (\%) }\end{array}$ & $\begin{array}{l}\text { years of } \\
\text { survey }\end{array}$ & location \\
\hline $\begin{array}{l}\text { MONICA, } \\
\text { Sweden }\end{array}$ & $52(30-74)$ & $903(62)$ & 48 & 1994 & suburban \\
$\begin{array}{l}\text { Hoorn, Neth- } \\
\text { erlands }\end{array}$ & $62(50-77)$ & $2364(71)$ & 46 & $1989-91$ & urban \\
$\begin{array}{l}\text { Newcastle, } \\
\text { U.K. }\end{array}$ & $55(30-76)$ & $778(91)$ & 52 & $1992-94$ & urban \\
\hline $\begin{array}{l}\text { KORA, Ger- } \\
\text { many }\end{array}$ & $64(55-74)$ & $1485(62)$ & 47 & $1999-01$ & $\begin{array}{l}\text { urban and } \\
\text { rural }\end{array}$ \\
\hline $\begin{array}{l}\text { Cremona, } \\
\text { Italy }\end{array}$ & $58(40-89)$ & $1672(87)$ & 44 & $1990-91$ & urban \\
\hline $\begin{array}{l}\text { Catalonia, } \\
\text { Spain }\end{array}$ & $54(30-89)$ & $1835(93)$ & 42 & 1994 & urban \\
\hline
\end{tabular}

lence was significantly higher in men than in women aged 55 to 59 years, whereas in elderly participants above 70 years of age no significant sex difference was observed. IGR prevalences in the KORA data were also higher in men than in women up to 70 years of age, however, which was statistically significant in the agegroup 60-69 years only $(p<0.01)$. It is noteworthy, that in subjects aged 60 to 69 years, IGR prevalence was higher in the KORA Survey than the average estimate from the DECODE Study, in particular, among men.

After applying the current inclusion criteria to the surveys, six population-based studies were selected for detailed comparisons (Sweden, U.K., Germany, the Netherlands, Italy, Spain). Their basic demographic data and participation (\%) are given in Table 2 . In most surveys, proportion of females was higher among participants. Overall, participation ranged from 62 to $93 \%$. Due to different age-strata used in the various publications, comparisons of total diabetes and IGR prevalences were limited to the age-group 60 to 69 years. This age group covers the largest number of subjects with glucose disorders in most European populations.

In Table 3, a ranking of diabetes and IGR prevalences in men and women is given for the six surveys. In both sexes, a wide variation of diabetes and IGR frequencies was found in European studies. Variation was about 2 fold for diabetes and $2-3$ fold for IGR prevalence. Both in men and women, the highest total diabetes prevalences were found in Catalonia (Spain) and in Augsburg (Germany). The lowest diabetes prevalence was observed in the Dutch Study (Hoorn). IGR prevalences were highest both in men and women in the surveys from Newcastle, Augsburg, and Catalonia. Again, estimates from the Dutch survey were substantially lower than in Augsburg. Thus, there appears to be a wide variation of diabetes and IGR prevalence in Western Europe. However, no clear geographical pattern could be found (i. e. north-south gradient).

\section{Discussion}

There is a wide variation of total diabetes prevalence in the elderly population in Western European countries without clear geographical pattern. Another recent study using European sentinel practice networks in eight countries confirms a two-fold range of prevalence of known diabetes, however, did not include Scandinavian countries and Germany [7].

Table 3 Sex-specific ranking of total diabetes (known and newly diagnosed) and impaired glucose regulation (IGR) prevalences in Western European population-based surveys in the age group $60-69$ years

\begin{tabular}{|c|c|c|c|c|c|c|c|}
\hline $\begin{array}{l}\text { diabetes prevalence } \\
\text { men }\end{array}$ & $\%$ & women & $\%$ & $\begin{array}{l}\text { IGR prevalence } \\
\text { men }\end{array}$ & $\%$ & women & $\%$ \\
\hline Catalonia, Spain & 18.6 & Catalonia, Spain & 25.3 & Newcastle, U.K & 39.6 & Catalonia, Spain & 24.6 \\
\hline KORA' ${ }^{1}$, Germany & 18.1 & MONICA, Sweden & 14.3 & Catalonia, Spain & 28.1 & KORA', Germany & 22.4 \\
\hline Newcastle, U.K. & 17.1 & Newcastle, U.K. & 13.9 & Hoorn, Netherlands & 21.7 & Hoorn, Netherlands & 18.0 \\
\hline
\end{tabular}

IGR: impaired glucose tolerance or impaired fasting glucose (1999 WHO criteria) ${ }^{1}$ survey S4 (1999/2001) 
Age, obesity, physical activity, nutrition, and genetic predisposition are relevant factors influencing diabetes prevalence in a population [8]. There are large differences in risk factors like obesity, diet, and sedentary lifestyle at the population level in Western Europe. Germany and the Netherlands are neighboring countries, whose populations largely share a similar genetic background. Nevertheless, there is a wide variation in diabetes prevalence in the elderly population, which was almost two-fold higher in Germany than in the Netherlands. This large difference is most likely still existing although the Dutch survey was carried out a decade earlier than the KORA Study. Prevalence of obesity, defined as BMI equal or above $30 \mathrm{~kg} / \mathrm{m}^{2}$, is about two-fold higher in Germany $(23 \%)$ than in the Netherlands $(12 \%)[9,10]$.

Among 15 member states of the EU, Dutch participants also reported the highest total physical activity in a recent survey [11]. A sedentary lifestyle is a major risk factor for type 2 diabetes. A lower prevalence of sedentary lifestyles was found in northern European countries, in particular, in Scandinavia, as compared with southern countries, especially the Mediterranean area [12]. A recent European survey, using an internationally validated questionnaire, confirmed higher prevalences of physical activity (recreation, sport, leisure-time activities) in the Netherlands and in Sweden than in Spain and Germany, corresponding to differences in diabetes prevalences found in the present study [13]. Therefore, the level of physical activity in a population could be an important predictor of diabetes prevalence.

Obesity and anthropometric measures like waist circumference also showed considerable variation within Western Europe [14, 15]. In particular, increased waist circumference has been found to predict type 2 diabetes [14]. Interestingly, in the EPIC study, highest values for waist circumference were observed in populations from southern Europe, in particular, Spain and Italy, corresponding to the high diabetes prevalences found in populationbased surveys [15].

Finally, there is a marked variation in nutrition in Western Europe, from timing of meals to the composition of foods [16]. The fatty acid composition of the diet is important in the development of type 2 diabetes [17]. A high intake of saturated fatty acids has been associated with an increased risk of progression to diabetes from IGT [17]. A north-south divide in nutrition is found in Europe: half of the dietary fatty acids in the south are monounsaturated whereas in the north, saturated fatty acids almost approach this proportion [16].

Thus, more comparative studies of type 2 diabetes and the predictive values of obesity, physical activity, and nutritional factors in the European population are of interest in the future. The effect of lifestyle factors may differ in various populations, and it will also be of interest, how risk factors like diet and physical activity interact with genetic markers.

Differences in body mass index within European populations only partly explain the large variation in diabetes prevalence [8]. It has been suggested that variation in diabetes prevalence between European OGTT-based surveys may partly be due to methodological differences in participation (selection bias) and in preanalytical and analytical study conditions with respect to the oral glucose tolerance test (i. e. physical activity, diet, smoking prior to OGTT; handling of glucose samples) [8]. Thus, it is conceivable that in fact existing geographic patterns of total type 2 diabetes prevalence in Europe could not be detected so far due to considerable misclassification of glucose tolerance groups in various surveys. Activities like the WHO MONICA project have provided evidence that regional variation in prevalence of a common non-communicable disease and its risk factors can successfully be monitored using standardized methods [14]. Thus, there is an urgent need for a standardized evaluation of type 2 diabetes prevalence in the whole European region, given the rising prevalence and enormous burden for the individual and the society.

\section{Future planning}

The KORA Survey S4 (1999/2001) included the first OGTT-based study on prevalence of undiagnosed diabetes and IGR in the elderly population in Germany. The prevalence of impaired glucose regulation (IGT and IFG) in Augsburg in the age group 60 to 69 years was higher than the European average found in the DECODE study. IGR is a strong risk factor for the future development of type 2 diabetes and cardiovascular disease [15]. In the Dutch Hoorn study, the five-year cumulative incidence of diabetes in participants with IGT was $33.8 \%$ and in subjects with additional IFG (fasting glucose $110-125 \mathrm{mg} / \mathrm{dl}$ ) up to $65 \%$ [15]. Thus, there is a huge reservoir for future diabetes cases in the elderly population in Germany. It has been estimated, that in 2000 in the age group 55 to 74 years about 3 million Germans had IGT, of whom a substantial number will develop diabetes within the next years [5]. Therefore, it is planned that all KORA Survey S4 (1999/2001) participants shall be invited for the F4 follow-up study in 2006/2007 (Institute of Biometrics and Epidemiology, German Diabetes Center, and Institute of Epidemiology, GSF). The aim is to evaluate for the first time the age- and sex-specific diabetes incidence and mortality (all-cause and cardiovascular) in a well-defined German population based on OGTT. These estimates will provide valuable information to estimate the extent of the future diabetes epidemic in the elderly population. Also for the first time a prospective study cohort of OGTT-based incident cases will be available for Germany, which is the preferred observational epidemiological study design for making causal inferences. Prospective studies on diabetes incidence are rare in Europe. Therefore, relevant future analyses of genetic and non-genetic risk factors of type 2 diabetes including their possible interactions will be possible [19].

\section{Acknowledgement}

The investigation has been supported by the GSF and the BMGS Federal Ministry of Health and Social Security, the Ministry of School, Science, and Research of the State of North-Rhine-Westfalia and the Anna Wunderlich-Ernst Jühling Foundation. 
The authors are indebted to K. Papke (head of KORA Study Center) and B. Schwertner (survey organization) and their coworkers for organizing and conducting the data collection. We also thank all participants of the OGTT study.

The article refers specifically to the following contribution of this special issue of Das Gesundheitswesen: [19-20, 22-31].

\section{Reference}

${ }^{1}$ International Diabetes Federation. Diabetes Atlas. Second Edition. Brussels, Belgium 2003

${ }^{2}$ Wild S, Roglic G, Green A et al. Global prevalence of diabetes. Estimates for the year 2000 and projections for 2030. Diabetes Care 2004; 27: 1047-1053

${ }^{3}$ De Beaufort CE, Reunanen A, Raleigh V et al. European union diabetes indicators. Fact or fiction? Eur J Publ Health 2003; 13: 51 - 54

${ }^{4}$ The DECODE Study Group. Age- and sex-specific prevalences of diabetes and impaired glucose regulation in 13 European cohorts. Diabetes Care 2003; 26: $61-69$

${ }^{5}$ Rathmann W, Haastert B, Icks A et al. High prevalence of undiagnosed diabetes mellitus in Southern Germany: target populations for efficient screening. The KORA Survey 2000. Diabetologia 2003; 46: $182-189$

${ }^{6}$ World Health Organisation (WHO). Definition, diagnosis and classification of diabetes mellitus and its complications. Part 1: Diagnosis and classification of diabetes mellitus. Report of a WHO consultation. Geneva: WHO, 1999

${ }^{7}$ Fleming DM, Schellevis FG, van Casteren V. The prevalence of known diabetes in eight European countries. Eur J Publ Health 2004; 14: $10-$ 14

${ }^{8}$ The DECODE Study Group, on behalf of the European Diabetes Epidemiology Group. Age, body mass index and glucose tolerance in 11 European population-based surveys. Diabetic Medicine 2002; 19: 558 565

${ }^{9}$ Helmert U, Strube H. The development of obesity in Germany in the period 1985 until 2000 (in German). Gesundheitswesen 2004; 66: 409-415

${ }^{10}$ Seidell JC, Visscher TL. Nutrition and health-obesity (in Dutch). Ned Tijdschr Geneeskd 2003; 147: 281 - 286

${ }^{11}$ Rütten A, Abu-Omar K. Prevalence of physical activity in the European Union. Soz Präventivmed 2004; 49: 281-289

12 Varo JJ, Martinez-Gonzalez MA, Irala-Estevez J et al. Distribution and determinants of sedentary lifestyles in the European Union. Int J Epidemiol 2003; 32: $138-146$

${ }^{13}$ European Opinion Research Group. Eurobarometer: Physical Activity. European Commission, 2003. http://europa.eu.int/comm/public opinion/archives (accessed: November 2004)

${ }^{14}$ Molarius A, Seidell JC, Sans S et al. Waist and hip circumferences, and waist-hip ratio in 19 populations of the WHO MONICA Project. Intern J Obes 1999; 23: 116-125

${ }^{15}$ Haftenberger M, Lahmann PH, Panico S et al. Overweight, obesity and fat distribution in 50- to 64-year-old participants in the European Prospective Investigation into Cancer and Nutrition (EPIC). Publ Health Nutr 2002; 5: $1147-1162$

${ }^{16}$ Gibney MJ. Nutrition, physical activity and health status in Europe: an overview. Publ Health Nutr 1999; 2: 329-333

${ }^{17}$ Mann JI. Diet and risk of coronary heart disease and type 2 diabetes. Lancet 2002; 360: 783-789

18 Unwin N, Shaw J, Zimmet P et al. Impaired glucose tolerance and impaired fasting glycaemia: the current status on definition and intervention. Diabetic Medicine 2002; 19: 708 - 723

${ }^{19}$ Herder C, Illig T, Rathmann W et al. Inflammation and Type 2 Diabetes: Results from KORA Augsburg. Gesundheitswesen 2005; 67 S1: S115-S121

${ }^{20}$ Löwel H, Döring A, Schneider A et al. The MONICA Augsburg surveys basis for prospective cohort studies. Gesundheitswesen 2005; 67 S1: S13-S18

${ }^{21}$ International Diabetes Federation. Diabetes Atlas. Second Edition. Brussels, Belgium 2003

22 Wichmann HE, Gieger C, Illig for the KORA Study Group T. KORA-gen Resource for population genetics, controls and a broad spectrum of disease phenotypes. Gesundheitswesen 2005; 67 S1: S26 - S30

${ }^{23}$ Löwel H, Meisinger C, Heier M et al. The population-based Acute Myocardial Infarction (AMI) Registry of the MONICA/KORA study region of Augsburg. Gesundheitswesen 2005; 67 S1: S31 - S37

${ }^{24}$ Döring A, Meisinger C, Thorand $B$ et al. Ernährungsverhalten und Übergewicht: Untersuchungen in den MONICA/KORA-Studien. Gesundheitswesen 2005; 67 S1: S51 - S56

25 Thorand B, Schneider A, Baumert J et al. Fall-Kohorten-Studien: Ein effektives Design zur Untersuchung von Biomarkern als Risikofaktoren für chronische Krankheiten - Darstellung am Beispiel der MONICA/ KORA Augsburg Fall-Kohorten Studie 1984 - 2002. Gesundheitswesen 2005; 67 S1: S98 -S102

${ }^{26}$ Meisinger C, Döring A, Heier M et al. Type 2 Diabetes mellitus in Augsburg - an epidemiological overview. Gesundheitswesen 2005; 67 S1: S103-S109

${ }^{27}$ Rathmann W, Haastert B, Icks A et al. The Diabetes Epidemic in the Elderly Population in Western Europe: Data from Population-Based Studies. Gesundheitswesen 2005; 67 S1: S110-S114

${ }^{28}$ Illig T, Bongardt F, Schöpfer-Wendels A et al. Genetics of Type 2 Diabetes: Impact of Interleukin-6 Gene Variants. Gesundheitswesen 2005; 67 S1: S122 - S126

${ }^{29}$ Mielck A, Reisig V, Rathmann for the KORA Study Group W et al. Health inequalities among persons with type 2 diabetes: The example of intermittent claudication. Gesundheitswesen 2005; 67 S1: S137S143

${ }^{30}$ Eller M, Satzinger W, Holle R et al. Disease Management Programme in Deutschland: Erste Reaktionen der Diabetiker. Gesundheitswesen 2005; 67 S1: S144-S149

${ }^{31}$ Icks A, Rathmann W, Haastert B et al. Cost-effectiveness of type 2 diabetes screening: Results from recently published studies. Gesundheitswesen 2005; 67 S1: S167-S171 